\title{
PENGEMBANGAN PERANGKAT PEMBELAJARAN LANGSUNG DENGAN ANIMASI BERBASIS FLASH PADA KUBUS DAN BALOK
}

\section{(Development Equipment of Direct Instruction With Flash Based Animation Media on The Topic Cube and Cuboid)}

\author{
Ria Fibriana Sari ${ }^{1}$, I Ketut Budayasa ${ }^{2}$, Agung Lukito ${ }^{3}$ \\ ${ }^{1}$ Universitas Negeri Surabaya, riafibrianasari74@gmail.com \\ 2Universitas Negeri Surabaya, ketutbudayasa@unesa.ac.id \\ 3Universitas Negeri Surabaya, agunglukito@unesa.ac.id
}

\begin{tabular}{l}
\hline \hline Info Artikel \\
\hline Received Feb 14, 2020 \\
Revised Feb 21, 2020 \\
Accepted Feb 27, 2020 \\
\end{tabular}

Kata Kunci:

Direct Intruction, Macromedia flash, cube and cuboid

\footnotetext{
Cara merujuk artikel

ini:

Sari R. F., Budayasa, I

Ketut, \& Lukito, A. (2020).

Pengembangan Perangkat

Pembelajaran langsung

dengan animasi berbasis

flash pada kubus dan

balok. Vygotsky: Jurnal

Pendidikan Matematika dan

Matematika, 2 (1), pp. 43-53

Diunduh dari https:/ /

jurnalpendidikan.

unisla.ac.id/index.php/VoJ

/article/view/191/pdf
}

\begin{abstract}
This research is triggered by low students learning outcomes in cube and cuboid material. The purpose of this research is to produce the direct learning based on Macromedia Flash device which can improve student learning outcomes in class VIII. Based on the results of the test device, obtained by the direct learning based on Macromedia Flash have been valid according to the validator and qualified: (1) the ability to manage the learning criteria of good teachers, (2) the activity of students active in the learning process, (3) Classical learning completeness reached, (4) students response positive a learning component, (5) the learning outcomes test meet the criteria for a valid, reliable, and sensitive. Thus, it can be concluded that problem based learning was effective.
\end{abstract}

\begin{tabular}{l}
\hline Abstrak \\
\hline Penelitian ini dilatarbelakangi oleh rendahnya hasil \\
belajar siswa pada materi kubus dan balok. Tujuan \\
penelitian ini adalah untuk menghasilkan perangkat \\
pembelajaran langsung dengan media animasi \\
berbasis Flash pada materi kubus dan balok untuk \\
siswa SMP kelas VIII. Berdasarkan hasil uji coba \\
perangkat, diperoleh perangkat pembelajaran \\
langsung berbasis Macromedia Flash valid menurut \\
para validator serta memenuhi kriteria: (1) \\
kemampuan guru mengelola pembelajaran \\
berkriteria baik, (2) aktivitas siswa dalam proses \\
pembelajaran baik, (3) respons siswa terhadap \\
komponen belajar positif, (4) tes hasil belajar \\
memenuhi kriteria valid, reliabel, dan sensitif. \\
Sehingga dapat disimpulkan bahwa perangkat \\
pembelajaran berkualitas baik.
\end{tabular}

Copyright (C) 2020 Vygotsky: Jurnal Pendidikan Matematika dan Matematika. All right reserved 


\section{PENDAHULUAN}

Sekolah merupakan lembaga pendidikan yang mengantarkan peserta didik untuk mengembangkan segala potensi yang dimilikinya. Bersekolah juga dipercaya sebagai cara terbaik agar manusia dapat hidup yang layak pada masa yang akan datang, keberhasilan disekolah tergantung pada proses belajar mengajar dikelas.

Faktor-faktor yang mempengaruhi belajar banyak jenisnya, tetapi dapat digolongkan menjadi dua golongan saja, yaitu faktor intern dan ekstern. Faktor intern adalah faktor yang ada dalam individu, sedangkan faktor ekstern adalah faktor yang ada diluar individu (Slamento, 2010:54). Salah satu faktor yang mempengaruhi proses belajar mengajar disekolah adalah media Pembelajaran yang diterapkan oleh guru. Media mempunyai banyak peran dalam proses pembelajaran (Mustaji, 2013:3)

Peter (dalam Sudjana, 2009:15) mengatakan "ada tiga tugas dan tanggung jawab guru, yakni: (a) guru sebagai pengajar, (b) guru sebagai pembimbing, dan (c) guru sebagai administator kelas". Selain itu dijelaskan juga bahwa guru sebagai pengajar lebih menekankan kepada tugas dalam merencanakan dan melaksanakan pengajaran. Dalam hal ini guru bertugas menyiapkan segala sesuatu dengan rencana, sehingga tujuan pembelajaran dapat tercapai. Salah satu tugas pendidik atau guru adalah menciptakan suasana pembelajaran dan dapat memotivasi siswa untuk senantiasa belajar dengan baik dan semangat. Suasana pembelajaran yang demikian akan berdampak positif dalam pencapaian prestasi belajar yang optimal. Oleh karena itu, guru sebaiknya memilih metode dan media pembelajaran yang tepat. Ketidaktepatan dalam penggunaan metode dan media akan menimbulkan kejenuhan bagi siswa dalam menerima materi yang disampaikan sehingga materi kurang dapat dipahami yang akan mengakibatkan siswa menjadi apatis.

Dalam pembelajaran diperlukan interaksi antara siswa dengan guru, dan interaksi yang baik akan tercapai jika terjadi komunikasi yang baik. Sudjana (2009:31) mengatakan "untuk mencapai interaksi belajar mengajar sudah barang tentu perlu adanya komunikasi yang jelas antara guru (pengajar) dengan siswa (pelajar), sehingga terpadunya dua kegiatan, yakni kegiatan mengajar (usaha guru) dengan kegiatan belajar (tugas siswa) yang berdayaguna dalam mencapai tujuan pengajaran". Dari pendapat yang dikemukakan oleh Sudjana tersebut dapat disimpulkan bahwa kegiatan belajar mengajar akan terlaksana dengan optimal dan mencapai tujuan yang diharapkan jika terjadi komunikasi yang baik antara guru sebagai pengajar dan siswa sebagai pebelajar.

Proses belajar mengajar merupakan suatu kegiatan melaksanakan kurikulum suatu lembaga pendidikan, agar dapat mempengaruhi siswa mencapai tujuan pendidikan yang telah ditetapkan. Tujuan pendidikan pada dasarnya mengantarkan para siswa menuju pada perubahanperubahan tingkah laku baik intelektual, moral maupun sosial agar dapat hidup mandiri sebagai individu dan makhluk sosial. Dalam mencapai tujuan tersebut siswa berinteraksi dengan lingkungan belajar. Lingkungan 
belajar diatur oleh guru mencakup tujuan pengajaran, bahan pengajaran, metodologi pengajaran dan penilaian pengajaran. Unsur-unsur tersebut biasa dikenal dengan komponen pengajaran. Tujuan pengajaran adalah rumusan kemampuan yang diharapkan dimiki para siswa setelah menempuh pengalaman belajar.

Bahan pengajaran adalah seperangkat materi keilmuan yang terdiri atas fakta, konsep, prinsip, generalisasi suatu pengetahuan yang bersumber dari kurikulum dan dapat menunjang tercapainya tujuan pengajaran. Metodologi pengajaran adalah metode dan teknik yang digunakan guru dalam melakukan interaksinya dengan siswa agar bahan pengajaran sampai pada siswa, sehingga siswa mengetahui tujuan pengajaran. (Sudjana dan Rivai, 2010:1)

Mengajar mengandung dua unsur yang penting yaitu metode mengajar dan media pengajaran. Kedua aspek ini saling berkaitan. Pemilihan salah satu metode mengajar tertentu akan mempengaruhi jenis media pengajaran yang sesuai, meskipun masih ada berbagai aspek lain yang harus diperhatikan dalam memilih media, antara lain tujuan pengajaran, jenis tugas dan respons yang diharapkan dapat dikuasai siswa setelah pengajaran berlangsung. Meskipun demikian, dapat dikatakan bahwa salah satu fungsi utama media pengajaran adalah sebagai alat bantu mengajar yang turut mempengaruhi iklim, kondisi, dan lingkungan yang diciptakan oleh guru (Djamarah, Syaiful Bahri dan Zain, $2012: 82)$.

Media pembelajaran merupakan segala sesuatu yang digunakan dalam kegiatan pembelajaran agar dapat merangsang pikiran, perasaan, minat dan perhatian siswa sehingga proses interaksi dan komunikasi edukasi antara guru (atau pembuat media) dan siswa dapat berlangsung secara efektif dan efisien.

Pendidikan dan media pembelajaran memiliki kaitan yang sangat erat, proses pembelajaran tidak akan berjalan lancar tanpa adanya media pembelajaran yang tepat. Media adalah perantara atau pengantar pesan dari pemberi kepada penerima pesan. Menurut AECT (Association of Education and Communication Technology, 2017), media adalah segala bentuk dan saluran yang digunakan orang untuk menyalurkan pesan atau informasi. Penggunaan media yang tepat mampu menyampaikan informasi maupun pesan yang disampaikan oleh penyampai pesan dapat diterima dengan jelas oleh penerima pesan. Begitu juga ketika media digunakan dalam proses pembelajaran di kelas, informasi yang disampaikan guru sebagai penyampai pesan di kelas dapat diterima dengan jelas oleh siswa sebagai penerima pesan di kelas.

Menurut Suhadi (2018) media pembelajaran yang kompeten adalah media yang mampu mengurangi verbalisme dan meletakkan dasar-dasar yang konkret dalam berpikir. Selaras dengan hal itu, Clark \& Paivio (2010) menyatakan bahwa informasi yang tersimpan dalam memori jangka panjang dalam dua bentuk yaitu visual dan verbal. Informasi yang disajikan secara visual dan verbal diingat lebih baik daripada informasi 
yang disajikan dengan salah satu cara. Untuk itu, seorang guru hendaknya mampu memfasilitasi terjadinya proses yang menghubungkan symbol secara bermakna dan dengan cara yang mudah diingat (Ibrahim, 2010).

Pemanfaatan TI dalam kegiatan pembelajaran tentu akan membawa perubahan atau budaya pembelajaran. Pemanfaatan TI dalam pembelajaran dapat menjadi sistem pembelajaran mandiri (instructor independent) atau juga digabungkan dengan proses pembelajaran langsung (tatap muka di kelas) yang mengandalkan kehadiran guru. Sebenarnya pemanfaatan media dalam dunia pendidikan sudah semakin meluas, perkembangan teknologi yang pesat menggakibatkan munculnya inovasi media pembelajaran yang menerapkan teknologi tinggi (high technology) misalnya computer. Materi pembelajaran dapat disajikan dalam bentuk interaktif berformat digital, sebuah konten pembelajaran menjadi lebih menarik, efektif dan fleksibel (Rosari, 2009). Hal ini membawa kecenderungan untuk menggunakan computer sebagai media pembelajaran dalam bentuk Computer Assited Instruction (CAI) atau juga dikenal dengan Pembelajaran Berbantuan Komputer (PBK). Menurut Kardi dan Nur (2015:4), Model Pembelajaran Langsung dirancang secara khusus untuk mengembangkan belajar siswa tentang pengetahuan procedural yaitu pengetahuan tentang bagaimana melakukan sesuatu dan pengetahuan deklaratif yaitu pengetahuan tentang sesuatu, yang diajarkan selangkah demi selangkah. Oleh Karena itu, penerapan model pembelajaran langsung dengan menggunakan TI dapat memudahkan guru dalam penyampaian materi sehingga mempercepat proses pembelajaran.

Media animasi dengan CAI hanya sebagai alat bantu guru dalam mengajar. Peran guru yang dimaksud yaitu menetapkan kapan CAI digunakan, berapa lama, dan bahan apa yang akan ditampilkan. Dengan memanfaatkan media pembelajaran, diharapkan guru dapat memperkaya, memperluas, dan memperdalam proses belajar-mengajar, terlebih bila tersedia media yang merangsang lebih dari satu organ penginderaan (Winkel, 2019).

Berdasarkan adanya kesenjangan tersebut, peneliti ingin mengembangkan sebuah media pembelajaran animasi yang ditampilkan melalui computer melalui sajian pembelajaran CAI. Pembelajaran melalui media animasi yang menampilkan gambar-gambar dan kata-kata yang bergerak diharapkan menarik bagi siswa dan memudahkan siswa untuk mempelajari suatu konsep yang abstrak.

Menurut Mardiyono (2015:31), matematika sebagai ilmu dasar merupakan objek yang bersifat abstrak. Semua objek dalam matematika bersifat abstrak, di antara materi yang sifatnya abstrak adalah geometri bangun ruang sisi datar.

Objek dari geometri bangun ruang sisi datar yang sifatnya abstrak yaitu kubus, balok, prisma dan limas. Adanya sifat abstrak ini mengakibatkan siswa sulit memahami dan menyerap materi 
pembelajaran. Sebagian besar siswa masih kesulitan dalam menyelesaikan soal yang berkaitan dengan materi bangun ruang sisi datar. Hal tersebut menjadi permasalahan yang rumit dan kompleks, bagi siswa yang memiliki kemampuan yang sedang-sedang saja, tentu akan membutuhkan waktu yang cukup lama untuk mempelajarinya. Untuk bias mempelajari dengan cepat, mudah, dan benar dalam materi pembelajaran bangun ruang sisi datar, maka diperlukan multimedia (program komputer) yang sesuai dengan isi pembelajaran. Diantara program computer yang interaktif dan komunikatif dalam penyampaian materi pembelajaran adalah adobe flash.

Adobe flash merupakan software presentasi yang memberikan kemudahan dalam mempresentasikan semua yang ada dalam konsep pembelajaran baik dalam bentuk audio visual, visualisasi yang bergerak atau animasi, serta interaktif (Hidayatullah, 2011:18). Flash didesain dengan kemampuan untuk membuat animasi dua dimensi yang handal dan ringan sehingga flash banyak digunakan untuk memberikan efek animasi pada website serta di dunia pendidikan digunakan untuk media pembelajaran, CD interaktif, dan game-game pendidikan. Produk yang dihasilkan dari perangkat lunak ini mempunyai file extensionswf.

Pada umumnya, terdapat banyak aplikasi pada program komputer yang dapat digunakan dalam kegiatan pembelajaran seperti microsoft power point atau open office presentation. Namun, kesederhanaan aplikasi ini memberikan batasan untuk bisa menampilkan presentasi visual yang menarik. Oleh karena itu, aplikasi multimedia seperti adobe flash bisa banyak membantu. Dalam proses pembelajaran, multimedia juga memiliki peranan penting dalam menentukan kualitas pendidikan. Oleh karena itu, guru yang cermat dan tanggap terhadap kebutuhan belajar siswa harus menggunakan metode dan media secara tepat dalam pembelajaran, sehingga siswa termotivasi terhadap pembelajaran (Ariyani dan Haryanto, 2010:122).

Berdasarkan uraian diatas, penulis akan melakukan penelitian dengan judul " Pengembangan Perangkat Pembelajaran Langsung Dengan Media Animasi Berbasis Flash Pada Materi Kubus Dan Balok Untuk Siswa SMP Kelas VIII ".

\section{METODE}

Penelitian ini digolongkan sebagai penelitian pengembangan, karena peneliti mengembangkan perangkat pembelajaran animasi berbasis flash pada materi kubus dan balok yang meliputi Rencana Pelaksanaan Pembelajaran (RPP), Lembar Kerja Siswa (LKS), dan Tes Hasil Belajar (THB). Pengembangan perangkat pembelajaran mengacu pada pengembangan model 4-D yang dikembangkan oleh Thiagarajan, Semmel, dan Semmel yang telah di modifikasi. Modifikasi yang dilakukan adalah penyederhanaan model dari empat tahap menjadi tiga tahap, yaitu pendefinisian (define), perancangan (design), dan pengembangan (develop). 
Rancangan, subjek, pelaksanaan dan tujuan uji coba ini dijelaskan sebagai berikut:

1) Subjek Uji coba

Subjek dalam uji coba ini adalah siswa kelas VIII SMPN 20 Surabaya pada mata pelajaran matematika tahun pendidikan 2018/2019. Jumlah subjek penelitian sebanyak 37 orang.

2) Rancangan Uji Coba

Rancangan uji coba perangkat pembelajaran menggunakan model one group pretest-postest design menurut Sugiyono (2010: 111). Rancangan penelitian ini dapat digambarkan sesuai berikut.

$$
\mathrm{T}_{1} \times \mathrm{T}_{2}
$$

\section{Gambar 1. The one group pretest-postest design}

Keterangan :

a. Diberikan pretest $\mathrm{T}_{1}$ untuk penguasaan siswa terhadap materi kubus dan balok sebelum kegiatan pembelajaran

b. Subjek dikenai perlakuan (X), yaitu kegiatan pembelajaran langsung berbasis Macromedia Flash

c. Diberikan Posttest $\mathrm{T}_{2}$ untuk mengetahui penguasaan siswa terhadap materi kubus dan balok setelah kegiatan pembelajaran

d. Soal $\mathrm{T}_{1}$ dan $\mathrm{T}_{2}$ dibuat sama dan digunakan untuk menentukan sensitivitas butir soal THB.1.

3) Tujuan pelaksanaan uji coba

Tujuan pelaksanaan uji coba perangkat pembelajaran (RPP dan LKS) adalah untuk mengetahui kesesuaian waktu yang direncanakan dalam RPP dengan pelaksanaan di lapangan dan untuk mengetahui kemampuan guru mengelola pembelajaran, mengetahui aktivitas siswa, serta mengetahui respons siswa terhadap komponen dan pelaksanaan pembelajaran. Hasil uji coba perangkat pembelajaran ini dianalisis untuk melakukan revisi perangkat draft III menjadi perangkat yang baik.

Sedangkan tujuan pelaksanaan tes hasil belajar siswa (THB) adalah untuk mengetahui kualitas tes yang dikembangkan, dalam hal ini akan dihitung validitas butir soal, reliabilitas butir soal, dan sensitivitas butir soal. Pelaksanaan tes dilaksanakan sebelum pelaksanaan pembelajaran (pre-tes) dan setelah pelaksanaan pembelajaran (post-tes). Hasil dari tes ini (berupa skor) kemudian dianalisis validitas, reliabilitas dan sensitivitas perangkat tes. Tes hasil belajar ini dikembangkan bersamaan dengan perangkat pembelajaran (RPP dan LKS), dan tidak digunakan untuk merevisi perangkat perangkat pembelajaran (RPP dan LKS), tetapi untuk merevisi tes itu sendiri. 


\section{HASIL DAN PEMBAHASAN}

\section{Hasil dan Proses Pengembangan Perangkat Pembelajaran}

Dari hasil yang telah diuraikan pada bab sebelumnya, maka diperoleh hasil sebagai berikut :

1. Perangkat pembelajaran

Berdasarkan hasil pada tahap validasi ahli menunjukkan bahwa perangkat pembelajaran langsung untuk materi kubus dan balok yang terdiri dari: Rencana Pelaksanaan Pembelajaran (RPP), Media Pembelajaran Berbasis Macromedia Flash, Lembar Kerja Siswa (LKS), dan Tes Hasil Belajar (THB) ditinjau dari indikator format, bahasa, isi, dan ilustrasi dikategorikan baik serta dapat digunakan dengan revisi kecil. Hal ini dibuktikan dengan nilai rata-rata setiap kriteria yang diberikan validator untuk setiap RPP, Media Flash dan LKS minimal cukup baik. Sedangkan hasil penilaian para validator terhadap THB secara umum adalah cukup valid, dapat dipahami, dan dapat digunakan dengan revisi kecil.

Pada tahap uji keterbacaan, umumnya semua siswa dapat mengerti dan memahami bahasa yang digunakan di Media, LKS dan THB. Dengan demikian tidak ada revisi pada Media, LKS dan THB. Pengamat untuk kemampuan guru mengelola pembelajaran dan pengamat untuk aktivitas siswa selama pembelajaran masing-masing mengerti dan memahami cara untuk mengisi lembar pengamatan.
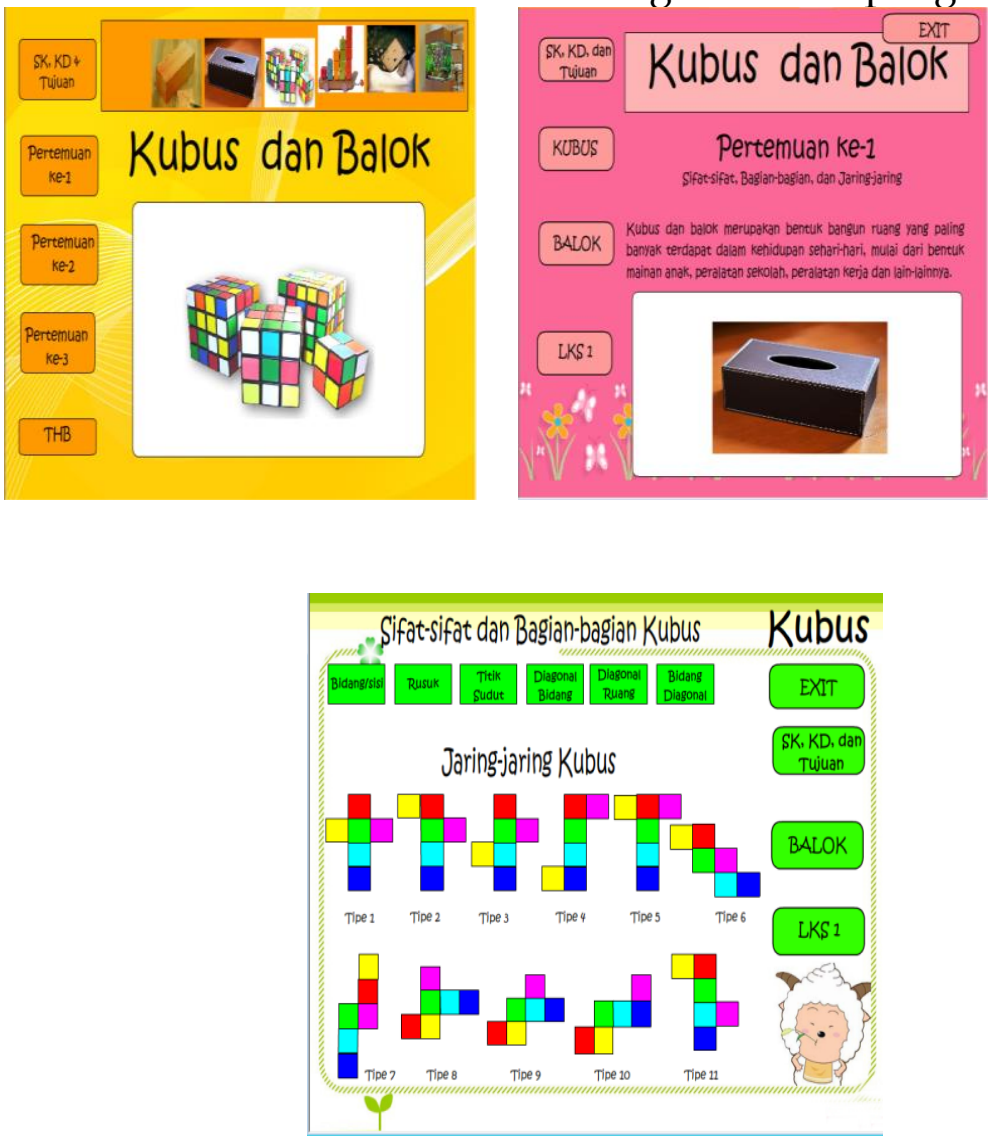

Gambar 2. Tampilan Media Flash 
2. Keterlaksanan pembelajaran oleh guru pada kelas uji coba dan kemampuan guru mengelola pembelajaran

Tingkat keterlaksanaan pembelajaran memenuhi kriteria sangat baik sehingga dapat disimpulkan pembelajaran mudah dan dapat digunakan oleh guru. Pada kegiatan awal guru mempersiapkan siswa belajar dengan memberikan motivasi, dan menyampaikan tujuan pembelajaran pada setiap pertemuan, kemampuan guru mengelola pembelajaran mencapai nilai minimal 4, hal ini berarti guru dapat menerapkan fase pertama pembelajaran langsung berbasis Macromedia Flash dengan minimal, seperti tampak pada Gambar 3.

Sedangkan pada kegiatan inti, guru mempresentasikan materi menggunakan media pembelajaran berbasis Macromedia Flash dengan baik, media pembelajaran berbasis Macromedia Flash dapat dengan mudah digunakan oleh guru. Kemudian guru membimbing siswa jika terdapat hal-hal yang tidak dimengerti siswa dalam menyelesaikan soal dan memberikan apresiasi kepada siswa yang sudah bekerja dengan sungguh-sungguh atau siswa yang sudah menyelesaikan soal seperti tampak pada Gambar 4.

Pada kegiatan akhir, guru membantu siswa menyimpulkan materi yang telah dipelajari dan menutup pembelajaran dengan memotivasi siswa mempelajari materi selanjutnya dengan baik. Pembelajaran yang dilakukan oleh guru sesuai dengan sintaks yang ada pada pembelajaran langsung berbasis Macromedia Flash. Guru melaksanakan pembelajaran sesuai dengan alokasi waktu dan membuat siswa antusias.

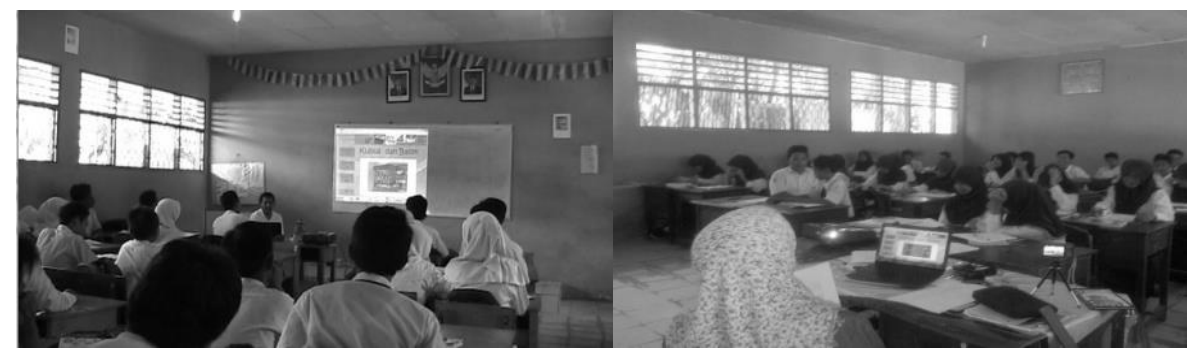

Gambar 3. Guru memberikan motivasi pada siswa
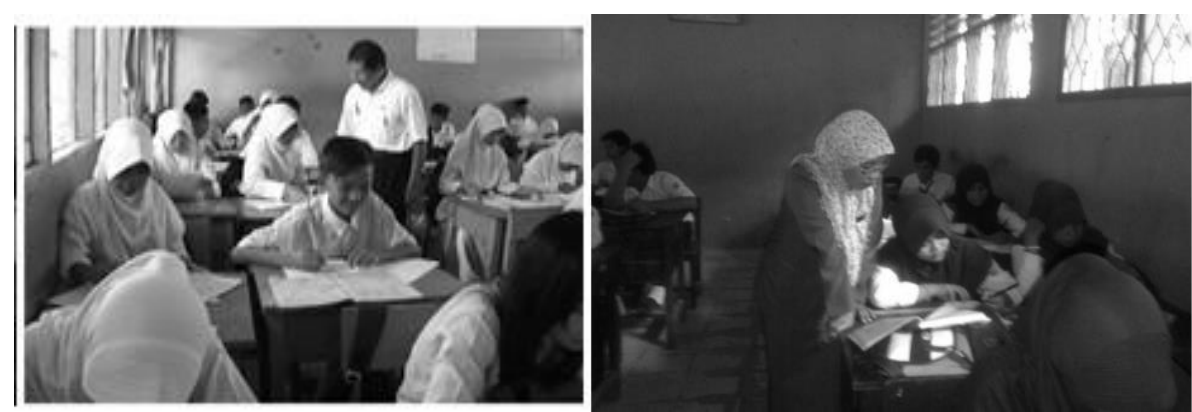

Gambar 4. Guru membimbing siswa jika terdapat hal-hal yang tidak dimengerti siswa dalam menyelesaikan soal 
3. Keterlaksaan pembelajaran oleh siswa pada kelas uji coba dan aktivitas ssiwa

Berdasarkan pengamatan pada kelas uji coba, keterlaksanaan pembelajaran oleh siswa memenuhi kriteria sangat baik sehingga dapat disimpulkan pembelajaran mudah dan dapat digunakan oleh siswa. Siswa dapat menggunakan LKS dan THB dengan baik. Berdasarkan hal tersebut dapat disimpulkan perangkat yang dikembangkan dapat digunakan dengan baik.

Kegiatan siswa yang dominan dilakukan selama pembelajaran adalah mengerjakan LKS, bertanya kepada guru jika ada mengalami kesulitan dalam mengerjakan LKS dan mempresentasikan hasil pekerjaan mereka di depan kelas.

4. Respons siswa

Berdasarkan data hasil penelitian pada kelas ujicoba diperoleh bahwa respons siswa terhadap komponen pembelajaran langsung berbasis Macromedia flash adalah positif, dan siswa berminat untuk mengikuti pembelajaran berikutnya dengan pembelajaran langsung berbasis Macromedia flash. Hal ini mengidentifikasikan bahwa pembelajaran tersebut dapat menumbuh kembangkan sikap positif siswa terhadap pembelajaran kubus dan balok khususnya dan matematika umumnya. Minat positif dari siswa akan membuat siswa antusias untuk belajar, sehingga siswa diharapkan dapat memperoleh hasil belajar yang lebih baik. Hal ini sesuai pendapat Suherman (1993:78) bahwa minat mempengaruhi proses dan hasil belajar.

5. Tes Hasil Belajar

Pemberian THB awal dan THB akhir di kelas uji coba digunakan untuk mengetahui kualitas butir tes hasil belajar yang dikembangkan. Instrumen tes hasil belajar yang dikembangkan berupa soal uraian berjumlah 6 butir soal. Hasil dari THB awal dan THB akhir siswa dianalisis untuk memeriksa validitas, reliabilitas, dan sensitivitas butir THB yang dikembangkan.

Berdasarkan analisis data tes hasil belajar, didapat koefisien validitas butir soal terendah adalah 0,477 dan koefisien validitas butir soal tertinggi adalah 0,76 sehingga kategori validitas termasuk dalam kategori sedang atau sangat tinggi. Jadi butir soal THB tersebut telah valid karena koefisien validitas tiap butir soal lebih dari 0,40 sehingga dapat dikatakan bahwa hasil tes hasil belajar ini sesuai dengan keadaan yang dievaluasi. Selain itu, diperoleh juga koefisien reliabilitas butir soal THB sebesar 0,647 sehingga butir soal THB tersebut telah reliabel karena koefisien reliabilitas lebih dari sama dengan 0,40. Jadi, tes hasil belajar ini dapat dipercaya karena memberikan hasil yang sama untuk subyek yang sama. Selanjutnya indeks sensitivitas butir soal terendah adalah 0,314 sehingga butir soal THB telah sensitif karena indeks sensitivitasnya lebih dari sama dengan 0,30. Jadi, tes hasil belajar ini cukup peka dan mampu membedakan tingkat kemampuan siswa sebelum dan sesudah 
menerima pembelajaran. dengan demikian, tes hasil belajar ini layak digunakan karena telah memenuhi kriteria valid, reliabel, dan sensitif.

\section{KESIMPULAN DAN SARAN}

\section{Kesimpulan}

Berdasarkan tujuan penelitian, hasil penelitian dan pembahasan hasil penelitian perangkat pembelajaran langsung berbantuan media flash pada materi kubus dan balok untuk siswa kelas VIII SMP diperoleh kesimpulan sebagai berikut:

1. Perangkat pembelajaran langsung pada media flash dikembangkan menggunakan model pengembangan $4 \mathrm{D}$ yang dimodifikasi yaitu define (pendefinisian), design (perancangan), develop (pengembangan). Adapun tahap disseminate (penyebaran) tidak dilakukan karena keterbatasan waktu.

2. Dengan menggunakan model pengembangan yang disebutkan pada kesimpulan I, diperoleh perangkat pembelajaran langsung berbasis Flash pada materi kubus dan balok untuk siswa SMP kelas VIII berkualitas baik. Hal ini dibuktikan dengan dipenuhinya kriteria berikut :

a. Untuk perangkat pembelajaran non THB diperoleh:

1) Perangkat pembelajaran dinyatakan valid oleh validator

2) Kemampuan guru dalam mengelola pembelajaran dikatakan baik

3) Aktivitas siswa dalam pembelajaran baik

4) Respons siswa terhadap pembelajaran positif

b. Untuk perangkat pembelajaran THB diperoleh:
1) Valid
2) Reliabel
3) Sensitif

\section{Saran}

Dengan memperhatikan hasil penelitian, peneliti menyarankan sebagai berikut:

1. Perangkat pembelajaran langsung berbantuan media flash dapat dijadikan sebagai salah satu alternatif perangkat pembelajaran matematika bagi guru dalam mengajarkan materi bangun ruang di sekolah menengah pertama.

2. Karena perangkat pembelajaran berbantuan media flash ini yang dihasilkan baik untuk 1 kelas (sekolah) saja, maka akan lebih baik apabila diujicobakan lagi di kelas (sekolah) lain dengan kondisi serupa.

3. Karena respons siswa terhadap perangkat pembelajaran berbantuan media flash ini positif, maka untuk lebih lanjut dapat dikembangkan penambahan perangkat berbantuan media flash pada materi yang lain. 


\section{DAFTAR RUJUKAN}

Association for Educational Communication and Technology. (2017). The

Definition of Educational Terminology. Washington. DC: Author.

Clark, J. M., \& Paivio, A. (2019). Dual Coding Theory and Education. Educational Psychology Review, 3(3), 149-210.

Djamarah, Syaiful, B., \& Azwan, Z. (2012). Strategi Belajar Mengajar. Jakarta: Rineka Cipta.

Hidayatullah, Priyanto, dkk. (2011). Animasi Pendidikan menggunakan Flash. Bandung:Informatika Bandung

Ibrahim, M. (2010). Peningkatan Kompetensi Pedagogi dan Kinerja MIPA. Malang. Pelatihan Guru MIPA

Kardi, S. (2013). Tujuan Pembelajaran Perumusan dan Penggunaannya. Surabaya: Universitas Negeri surabaya.

Munadi, Y. (2018). Media Pembelajaran. Jakarta: Gaung Persada Press.

Mustaji. (2013). Media Pembelajaran. Surabaya: Unesa Press.

Nur, M., \& Wikandari, P. R. (2018). Pengajaran Berpusat Kepada Siswa dan Pendekatan Konstruktivis Dalam Pengajaran. Surabaya: Pusat Sains dan Matematika Sekolah (PSMS) Universitas Negeri Surabaya.

Rosari, R. W. (2009). Special Workshop: Macromedia Captivate. Semarang: Offset.

Rustaman, N. (2015). Strategi Belajar Mengajar Matematika. Malang: UM Press.

Sadiman, A. S. (2010). Media Pendidikan. Jakarta: PT. Raja Grafindo Persada.

Slamento. (2010). Belajar Dan Faktor-Faktor Yang Mempengaruhinya. Jakarta: PT. Rineka Cipta

Sudjana \& Ahmad, R. (2010). Media Pengajaran. Bandung: Sinar Baru Algensindo

Sudjana, N. (2009). Dasar-Dasar Proses Belajar Mengajar. Bandung: Sinar Baru Algensindo.

Suhardi. (2018). Media Pendidikan Matematika. Jakarta: Dirjen PMPTK Depdiknas.

Winkel, W, (2019). Psikologi Pengajaran. Jakarta: PT. Gramedia Widiasarana Indonesia. 